\title{
OCCURRENCE AND ANTIBIOTIC SENSITIVITY OF BACTERIA PRESENT IN THE CERVICAL MUCUS OF COWS IN LATE PUERPERIUM AND POSTPUERPERAL PERIOD
}

\author{
Z. VLČEK and RƯŽENA SVOBODOVÁ \\ Department of Farm Animal Reproduction and Surgery, University of Veterinary Science, \\ 61242 Brno
}

Received fuly 23, 1981

\begin{abstract}
Vlček, Z., Svobodová, Rưžena: Occurrence and Antibiotic Sensitivity of Bacteria Present in the Cervical Mucus of Cows in Late Puerperium and Postpuerperal Period. Acta vet. Brno, 54, 1985: 91-97.

In this study 282 Czech Pied cows were investigated to determine the species representation and relative numbers of bacteria contaminating the cervical mucus during late postpartum and at the beginning of a new reproductive cycle. The occurrence of bacteria was relatively rare and their numbers showed a decline in the period under study. A higher number of bacteria in the cervical mucus was found in late postpartum in cows not yet cycling. With restoration of the reproductive cycle, however, the occurrence and numbers of bacteria decreased. Of the identified bacteria saprophytic and facultatively pathogenic species predominated; rarely pathogenic species were isolated. Of the antibiotics tested in vitro the best inhibitory effects were obtained with chloramphenicol and oxytetracycline.
\end{abstract}

Reproductive organs, late postpartum period, bacterial contamination, insemination.

Physiology of puerperium has recently been given much attention in connection with etiology, therapy and prevention of conditions complicating its course and subsequent fertility.

In the present paper one important factor affecting the course of the postpartum period is considered, namely the bacterial microflora of the reproductive organs. This work is an extention of previous reports dealing with the dynamics of bacterial contamination of the uterus in cows in the early postpartum period (Vlček 1969; Kudláč and Vlček 1970; Filáček 1967; Kudláč et al. 1970); bacterial analysis of postpartum infections and intoxications; determination of the sensitivity to antibiotics of bacteria isolated from the reproductive organs of cows with and without complications during the postpartum period (Vlček 1962; Kubík and Grygar 1978); determination of stability of chlortetracycline introduced into the uterus; and the course of bacterial contamination of the uterus after the application of chlortetracycline (Vlček and Valenta 1976; Vlček and Němeček 1976).

De Bois (1961) found in two groups of cows that the uterine secretions of 40 and $58 \%$ of animals were contaminated by polybacterial microflora on day 10 post partum, on day 20 bacteria were found in only $25 \%$ of animals, on day 30 in $22 \%$ of the cows. At first insemination, bacterial contamination was found in $3 \%$ of cows examined; at second insemination no bacteria were detected. Normal uterine secretions were collected from cows with no obvious postpartum complications. On day 10 postpartum the secretions contained bacteria in in $30 \%$ of the cows, on day 20 in $19 \%$, on day 30 in only $5 \%$. Lloyd et al. (1968) cultured streptococci, staphylococci, micrococci, corynebacteria, pseudomonads and several Escherichia species from samples obtained by uterine lavage or endometrial biopsy of 106 postpartum cows. They observed a progressive reduction in the bacterial flora with advancing uterine involution. Bacteria were found in the uterus of $93 \%$ of cows during the first 14 days after parturition, but that percentage declined to $9 \%$ between days 46-60 post partum. Buchholz et al. (1979) observed Corynebacterium pyogenes often in mixed culture with anaerobes during the pathological course of the postpartum period in cows. Boitor et al. (1976) found a positive direct correlation between the declining number the uterine bacterial population and the degree of involution in cows with physiological course of the postpartum period and between the lochial leukocyte count and uterine involution. Georgiev (1978) 
found the duration of the postpartum period to be dependent on the immune response of the body, i. e. in cows with physiological postpartum period higher agglutinine titres were found, there was a higher phagocytic activity of leukocytes, and there was a lower uterine bacterial population. Luginbühl and Küpfer (1980) have shown that the bacterial numbers in the uterus are considerably influenced by the course of involution and by ovarial follicular activity.

Introduction of highly efficacious antibiotics has substantially improved therapy of bacteriai diseases. On the other hand, new problems have emerged with their use. i.e. increased resistance of bacterial strains resulting in decreased effectiveness of antibiotics in long-term therapy, both enhanced by application of insufficient doses of antibiotics and failing to observe the rules of antibiotic therapy. Broad use of low levels of antibiotics in feed mixtures has also contributes to the resistance of bacteria to antibiotics (Milovský 1979; Pohl and Thomas 1979). Significant changes in susceptibility to antibiotics was found in many pathogenic and potentially pathogenic bacterial strains (Söveges and Molnár 1976; Hypa and Kahlcke 1978; Trolldenier 1980). Intrauterine administration of antibiotics will also result in the accumulation of detectable amounts of their residues in food products (Berchtold and Müller 1976).

Extensive practical experience combined with routine laboratory examination and culturing has shown that the species representation of bacteria involved in the infection of the reproductive organs of the cow during the postpartum period, often resulting in fertility disorders, may vary considerably among various localities. Therefore it is desirable to culture initially to determine the antibiotic sensitivity of the bacteria involved prior to start of antibiotic therapy (Buchholz et al. 1979; Vlček 1962; Lassó an Neogrády 1980). In acute cases, broad-spectrum antibiotics are indicated. Periodic tests of antibiotic sensitivity to pathogens present in the respective herds should be carried out in order to ensure efficacy of drug therapy.

\section{Materials and Methods}

This was a study of 282 cows observed for uterine involution and until the beginning of a new reproduction cycle (12-80 days post partum) samples of cervical mucus were collected using a special device. The samples were cultured in meat-peptone agar enriched with ram erythrocytes, incubated for $48-72 \mathrm{~h}$ under aerobic conditions at $37^{\circ} \mathrm{C}$ and a relative humidity of $70-80 \%$. Determined were the bacterial species, their relative numbers, and the duration of their presence in the cervical mucus of cows not yet showing signs of the first estrus after parturition. These were contrasted with results from cows with a restored cycle, and with the effect of age of the animals in the presence of bacterial contaminants. Subcultures of 138 bacterial strains were tested for sensitivity to antibiotics most frequently employed on farms (penicillin, streptomycin, tetracyclin, oxytetracyclin, chloramphenicol and neomycin) using the disc method (Sensitivity Discs, Lachema). Sensitivity of organisms was determined by the degree of growth inhibition and described as very sensitive, sensitive and non-sensitive strains.

\section{Results and Discussion}

In the late postpartum and postpuerperal periods of the majority of the cows low bacterial numbers were present in cervical mucus, in agreement with the above-cited papers (Filáček 1967; Vlček 1969; DeBois 1961; Lloyd et al. 1968). The results obtained in 251 cows are summarized in Table 1 indicating that in animals with a physiological duration of the postpartum period heavy contamination $(++t)$ was found in only $2.78 \%$. In the majority of cows presenting positive findings, only solitary colonies were found $(26.69 \%)$; medium contamination was detected in $12.74 \%$ of the cows. Negative results were obtained in $57.76 \%$ of the cows. Table 1 also shows that the occurence and numbers of bacteria in the cervical mucus decreased with time in the postpartum period and the first postpartal inseminations. This finding is in keeping with the known beneficial effect of restored ovarian follicular activity upon defence mechanisms of the reproductive organs. This process in under neurohumoral regulation and it plays an important role in preparation for a new conception and pregnancy. The values shown in Table 2 indicate that a heavier bacterial contamination was found in cows with the reproductive cycle not restored as yet, in cows with pathologically prolonged postpartum anestrus $(62.16 \%$ 
and $60.00 \%$, respectively), whereas in animals with restored cycle it was considerably less $(49.90 \%$ and $35.36 \%$ ). Small numbers of positive findings in cows with the ovarial cyst syndrome may be explained by persisting estrogen production as the clinical symptoms were mostly indicative of follicular cysts.

In Table 3 the degree of bacterial contamination of the cervical mucus as related to the age of cows is given. The results indicate that, overall, the bacterial numbers

Table 1

Bacterial contamination of the cervical mucus of cows in late puerperium and at the beginning of a new reproduction cycle as related to days post partum (\%)

\begin{tabular}{|l|c|c|c|c|c|c|}
\hline \multirow{2}{*}{$\begin{array}{c}\text { Days post } \\
\text { partum }\end{array}$} & $\mathrm{n}$ & \multicolumn{2}{|c|}{ Degree of bacterial contamination } & \multicolumn{2}{|c|}{ Total } \\
\cline { 3 - 7 } & & I & II & III & positive & negative \\
\hline $12-20$ & 41 & 31.70 & 24.39 & 2.43 & 58.53 & 46.46 \\
$21-30$ & 49 & 36.73 & 4.08 & 0 & 40.81 & 59.18 \\
$31-40$ & 86 & 20.93 & 12.79 & 6.97 & 40.69 & 59.30 \\
$41-50$ & 35 & 25.71 & 17.14 & 0 & 42.85 & 57.14 \\
$51-60$ & 22 & 22.72 & 4.54 & 0 & 27.27 & 72.72 \\
61 and more & 18 & 22.22 & 11.11 & 0 & 33.33 & 66.66 \\
\hline
\end{tabular}

I single colonies not surpassing 6

II medium contamination up to 20 colonies

III more than 20 colonies

From a group of 282 cows, 31 animals were not included for prolonged postpartal anestrus and for ovarial cyst syndrome.

Table 2

Bacterial contamination of the cervical mucus of cows in late puerperium and at the beginning of a new reproduction cycle as related to restored cycling $(\%)$

\begin{tabular}{|c|c|c|c|c|c|c|c|}
\hline & & \multirow{2}{*}{$\mathrm{n}$} & \multicolumn{3}{|c|}{$\begin{array}{l}\text { Degree of bacterial } \\
\text { contamination }\end{array}$} & \multicolumn{2}{|c|}{ Total } \\
\hline & & & I & II & III & positive & negative \\
\hline \multirow[t]{2}{*}{$\begin{array}{l}\text { A } \\
\text { cows not yet cycling } \\
\text { after parturition }\end{array}$} & $\begin{array}{l}\text { physiological } \\
\text { postpartal } \\
\text { anestrus }\end{array}$ & 37 & 40.54 & 18.91 & 2.70 & 62.16 & 37.83 \\
\hline & $\begin{array}{l}\text { prolonged } \\
\text { postpartal } \\
\text { anestrus }\end{array}$ & 5 & 40.00 & 20.00 & 0 & 60.00 & 40.00 \\
\hline \multirow{2}{*}{$\begin{array}{l}\text { B } \\
\text { cows with confirmed } \\
\text { follicular activity } \\
\text { and cycling }\end{array}$} & $\begin{array}{l}\text { proestrus } \\
\text { and estrus }\end{array}$ & 132 & 26.51 & 11.36 & 3.03 & 40.90 & 59.09 \\
\hline & $\begin{array}{l}\text { metestrus } \\
\text { and diestrus }\end{array}$ & 82 & 20.73 & 12.19 & 2.43 & 35.36 & 64.63 \\
\hline $\begin{array}{l}\text { C } \\
\text { cows with disturbances } \\
\text { of cycle }\end{array}$ & $\begin{array}{l}\text { ovarial cyst } \\
\text { syndrome }\end{array}$ & 26 & 19.23 & 0 & 3.84 & 23.07 & 76.92 \\
\hline
\end{tabular}

For footnotes see Table 1 
Table 3

Bacterial contamination of the cervical mucus in late puerperium and at the beginning of a new reproduction cycle as related to the age of cows ( $\%)$

\begin{tabular}{|c|c|c|c|c|c|c|c|c|c|}
\hline \multirow{2}{*}{$\begin{array}{l}\text { Age } \\
\text { years }\end{array}$} & \multirow{2}{*}{$\begin{array}{c}\text { Days after } \\
\text { parturition }\end{array}$} & \multirow{2}{*}{$\mathrm{n}$} & \multicolumn{5}{|c|}{ Degree of bacterial contamination } & \multirow{2}{*}{$\begin{array}{c}\text { Total } \\
\text { number } \\
\text { of cows }\end{array}$} & \multirow{2}{*}{$\begin{array}{c}\text { Total } \\
\text { positive }\end{array}$} \\
\hline & & & negative & $\mathbf{I}$ & II & III & positive & & \\
\hline $2-3$ & $\begin{array}{l}12-20 \\
21-30 \\
31-40 \\
41-50 \\
51 \text { and more }\end{array}$ & $\begin{array}{l}23 \\
18 \\
38 \\
19 \\
34\end{array}$ & $\begin{array}{l}52.17 \\
66.66 \\
60.52 \\
52.63 \\
73.52\end{array}$ & $\begin{array}{l}21.73 \\
27.27 \\
26.31 \\
31.57 \\
17.64\end{array}$ & $\begin{array}{r}26.08 \\
5.55 \\
5.26 \\
15.78 \\
8.82\end{array}$ & $\begin{array}{c}0 \\
0 \\
7.89 \\
0 \\
0\end{array}$ & $\begin{array}{l}47.82 \\
33.33 \\
39.47 \\
47.36 \\
26.47\end{array}$ & 132 & 37.87 \\
\hline $4-5$ & $\begin{array}{l}12-20 \\
21-30 \\
31-40 \\
41-50 \\
51 \text { and more }\end{array}$ & $\begin{array}{r}9 \\
26 \\
33 \\
12 \\
12\end{array}$ & $\begin{array}{l}11.11 \\
57.69 \\
66.66 \\
66.66 \\
75.00\end{array}$ & $\begin{array}{l}55.55 \\
38.46 \\
15.15 \\
25.00 \\
25.00\end{array}$ & $\begin{array}{r}33.33 \\
3.84 \\
12.12 \\
8.33 \\
0\end{array}$ & $\begin{array}{c}0 \\
0 \\
6.06 \\
0 \\
0\end{array}$ & $\begin{array}{l}88.88 \\
42.30 \\
33.33 \\
33.33 \\
25.00\end{array}$ & 92 & 40.21 \\
\hline $6-7$ & $\begin{array}{l}12-20 \\
21-30 \\
31-40 \\
41-50 \\
51 \text { and more }\end{array}$ & $\begin{array}{r}7 \\
3 \\
17 \\
5 \\
9\end{array}$ & $\begin{array}{l}57.14 \\
66.66 \\
47.05 \\
40.00 \\
55.55\end{array}$ & $\begin{array}{l}14.28 \\
33.33 \\
23.52 \\
40.00 \\
22.22\end{array}$ & $\begin{array}{l}14.28 \\
0 \\
23.52 \\
20.00 \\
11.11\end{array}$ & $\begin{array}{c}14.28 \\
0 \\
5.88 \\
0 \\
11.11\end{array}$ & $\begin{array}{l}42.85 \\
33.33 \\
52.94 \\
60.00 \\
44.44\end{array}$ & 41 & 48.78 \\
\hline 8 and more & $\begin{array}{l}12-20 \\
21-30 \\
31-40 \\
41-50 \\
51 \text { and more }\end{array}$ & $\begin{array}{l}2 \\
3 \\
5 \\
4 \\
3\end{array}$ & $\begin{array}{c}0 \\
33.33 \\
60.00 \\
50.00 \\
100.00\end{array}$ & $\begin{array}{c}100.00 \\
66.66 \\
20.00 \\
25.00 \\
0\end{array}$ & $\begin{array}{c}0 \\
0 \\
20.00 \\
25.00 \\
0\end{array}$ & $\begin{array}{l}0 \\
0 \\
0 \\
0 \\
0\end{array}$ & $\begin{array}{c}100.00 \\
66.66 \\
40.00 \\
50.00 \\
0\end{array}$ & 17 & 47.05 \\
\hline Total & $\begin{array}{l}12-20 \\
21-30 \\
31-40 \\
41-50 \\
51 \text { and more }\end{array}$ & $\begin{array}{l}41 \\
50 \\
93 \\
40 \\
58\end{array}$ & $\begin{array}{l}41.46 \\
60.00 \\
60.21 \\
55.00 \\
72.41\end{array}$ & $\begin{array}{l}31.70 \\
36.00 \\
21.50 \\
30.00 \\
18.96\end{array}$ & $\begin{array}{r}24.39 \\
4.00 \\
11.82 \\
15.00 \\
6.89\end{array}$ & $\begin{array}{l}2.43 \\
0 \\
6.45 \\
0 \\
1.72\end{array}$ & $\begin{array}{c}58.53 \\
40.00 \\
39.78 \\
45.00 \\
27.58\end{array}$ & 282 & 40.78 \\
\hline
\end{tabular}

For footnotes see Table 1

were higher in cows aged $6-7,8$ and more years $(48.78 \%$ and $47.05 \%$ positive findings) than in the younger animals aged $2-3$ and $4-5$ years $(37.87 \%$ and $40.21 \%$, respectively). A comparison of the bacterial numbers among the various age groups as related to the time after parturition is difficult to make due to the small numbers of bacteria.

Identification of the bacteria revealed mostly saprophytic and facultatively pathogenic species. Occasionally pathogenic species were detected. Of the saprophytic species the Micrococcaceae family predominated with saprophytic species of the genera Micrococcus and less frequently Staphylococcus (more often S. epidermidis than $S$. aureus), further Gaffkya tetragena and Sarcina sp. were isolated. From the family, Streptococcaceae $S$. acidominimus and other viridans species, $S$. faecalis, $S$. faecalis subspecies zymogenes, other, but non-identified streptococci of the serologic group D. Other isolates were made of saprophytic species of the family Corynebacteriaceae - the genera Corynebacterium and Microbacterium, occasionally facultatively pathogenic species $C$. pyogenes; of the family Bacillaceae saprophytic species of the genus Bacillus, of the family Enterobacteriaceae the species Citrobacter intermedius and Escherichia coli were isolated. This spectrum is, no doubt, broader as many species with more specific growth requirements could not be isolated by the methods employed.

In Table 4 the sensitivity of these microorganisms to the antibiotics most frequently used in practice is summarized. The results indicate that with streptomycin and neomycin, more resistant strains were found that with other antibiotics, and only a few were not susceptible to chloramphenicol. Among the antibiotics, differences were 
Table 4

Antibiotic eensitivity of bacteria leolated from cervical mucus of cows in late puerperium and at first postpartal inseminations

\begin{tabular}{|c|c|c|c|c|c|c|}
\hline Antibiotic & Penicillin & $\begin{array}{c}\text { Strepto- } \\
\text { mycin }\end{array}$ & Neomycin & $\begin{array}{l}\text { Tetra- } \\
\text { cycline }\end{array}$ & $\begin{array}{c}\text { Oxytetra- } \\
\text { cycline }\end{array}$ & $\begin{array}{c}\text { Chloramphe- } \\
\text { nicol }\end{array}$ \\
\hline $\begin{array}{l}\text { No. tested bacterial } \\
\text { strains }\end{array}$ & 73 & 138 & 138 & 138 & 138 & 138 \\
\hline $\begin{array}{l}\text { highly sensitive } \\
\text { bacterial strains \% }\end{array}$ & 10.95 & 81.15 & 78.26 & 77.53 & 84.05 & 67.39 \\
\hline $\begin{array}{l}\text { sensitive bacterial } \\
\text { strains } \%\end{array}$ & 79.45 & 4.34 & 7.97 & 12.31 & 7.97 & 28.98 \\
\hline $\begin{array}{l}\text { sensitive bacterial } \\
\text { strains } \% \text { total }\end{array}$ & 90.41 & 85.50 & 86.23 & 89.85 & 92.02 & 96.37 \\
\hline $\begin{array}{l}\text { non-sensitive } \\
\text { bacterial strains \% }\end{array}$ & 9.58 & 14.49 & 13.76 & 10.14 & 7.97 & 3.62 \\
\hline
\end{tabular}

Table 5

Antibiotics of choice selected on basis of in vitro sensitivity of bacteria isolated from the cervical mucus of cows in the period of 12 to 80 days after parturition

\begin{tabular}{|l|c|c|c|c|c|c|}
\hline \multicolumn{1}{|c|}{ Antibiotic } & $\begin{array}{c}\text { Chloramphe- } \\
\text { nicol }\end{array}$ & $\begin{array}{c}\text { Oxytetra- } \\
\text { cycline }\end{array}$ & $\begin{array}{c}\text { Tetra- } \\
\text { cycline }\end{array}$ & Penicillin & Neomycin & $\begin{array}{c}\text { Strepto- } \\
\text { mycin }\end{array}$ \\
\hline $\begin{array}{l}\text { No. tested bacterial } \\
\text { strains } \\
\text { highest efficacy \% }\end{array}$ & 138 & 138 & 138 & 73 & 138 & 138 \\
$\begin{array}{l}\text { 2nd highest } \\
\text { efficacy \% }\end{array}$ & 44.20 & 23.91 & 10.14 & 31.50 & 7.24 & 1.44 \\
$\begin{array}{l}\text { 3rd highest } \\
\text { efficacy \% }\end{array}$ & 25.36 & 28.26 & 23.91 & 6.84 & 16.54 & 6.52 \\
$\begin{array}{l}\text { Evaluated among 3 most } \\
\text { efficacious antibiotics }\end{array}$ & 85.50 & 71.73 & 64.49 & 54.79 & 4.96 & 13.76 \\
\hline
\end{tabular}

In case identical efficacies both antibiotics are given

found in numbers of sensitive and poorly sensitive bacterial strains; e.g. $84.05 \%$ of strains were susceptible to oxytetracycline but only $10.95 \%$ were susceptible to penicillin. Except for penicillin, the majority of tested strains has shown good sensitivity to the antibiotics employed. However, in this study mostly saprophytic organisms were found, some of which are often isolated from the reproductive organs of healthy cows with no fertility disturbances. Therefore it is difficult to make a valid comparison of these data with the results obtained in cows showing a pathological course of puerperium. In such animals considerably larger numbers of facultatively pathogenic and pathogenic microbial species were isolated along with a larger proportion of resistant strains. The majority of tested bacterial strains were susceptible to chloramphenicol $(96.37 \%)$ and oxytetracycline $(92.02 \%)$. Similar results were obtained when evaluating the suitability of antibiotics based on in vitro growth inhibitory tests (Table 5). Here, too, chloramphenicol was found to be among the most efficacious antibiotics in $85.5 \%$ and oxytetracycline in $71.73 \%$ of tested bacterial strains. 


\section{Výskyt bakterií $\mathrm{v}$ cervikálním hlenu krav $\mathrm{v}$ pozdním puerperiu a postpuerperálním období a jejich citlivost $k$ antibiotikưm}

U 282 krav českého strakatého skotu $\mathrm{v}$ pozdním puerperiu a na začátku nového reprodukčního cyklu byla sledována dynamika výskytu, množství, druhová skladba bakteriální kontaminace cervikálního hlenu a citlivost bakterií $\mathrm{k}$ antibiotikům. Výskyt bakterií a jejich množství byly celkově malé a měly v sledovaném období sestupný trend. Větší kontaminace cervikálního hlenu byla zjištěna $\mathrm{v}$ pozdním puerperiu $\mathrm{u}$ krav dosud necyklujících, s prodlužováním doby po porodu a obnovením pohlavního cyklu se výskyt a množství kontaminantů snížily. $\mathrm{V}$ identifikované mikrofloře převládaly saprofytické a př́ležitostně patogenní druhy bakterií, výskyt patogenních druhů byl ojedinělý. $Z$ testovaných antibiotik vykázal in vitro nejlepší tlumivý efekt na zjištěnou mikrofloru chloramfenikol a oxytetracyklin.

\section{Наличие бактерий в слизи шейки матки коров в позднем пуэрперии и в постпуэрперальный период и их чувствительность к антибиотикам}

У 282 коров племени чешокая пеструшка проводились исследования динамики наличия, количество и видов бактериальной контаминации слизи шейки матки а также чувствительности бактерий к антибиотикам в поздний пуэрперий и в начале нового цикла репродукции. Наличие бактерий и их количество были в итоге незначительные и в исследуемый период отличались тенденцией к уменьшению. Контаминация слизи шейки матки побольше была установлена в позднем пуэрперии у коров, не имевших до сих пор цикличности, с увеличением сроков после отела и восстановлением полового цикла наличие и количество бактерий понизилось. В определяемой микрофлоре преобладающими были сапрофитные и случайно патогенные виды бактерий, наличие патогенных видов было исключительным. Из проверяемых антибиотиков самым большим эфектом, смягчающим установленную микрофлору, в пробирке отличались хлорамфеникол и тетрациклин.

\section{References}

De BOIS, C. H. W.: Endometritis en vruchtbaarheid bij het rund. Thesis Utrecht 1961, 146 p. BERCHTOLD, M. - MÚLLER, R.: Zur Haftpflicht des Tierarztes beim Nachweis von Hemmstoffen in der Milch nach antibiotischen Uterus-Benadlungen. Schw. A. Tierheilkde, 118, 1976: $279-283$.

BOITOR, I. - DRAGHICI, C. - GABOREANU, M. - CRISTEA, E. - BOITOR, M.: Die Dynamik der Leukozyten und der Mikroflora des Uterusinhaltes im normalen und pathologischen Puerperium und bei chronischen Endometritiden des Rindes. Dtsch. t. Wschr. 83, 1976: $24-25$.

BUCHHOLZ, G. W. - NATTERMANN, H. - STUMPE, K.: Untersuchungen in einem Rinderbestand über Beziehungen zwischen Puerperalverlauf und Bakterienflora des Uterus. Mh. Vet. Med., 34, 1979: 372-376.

FILÁCEK, V.: Dynamika bakteriální kontaminace dělohy u krav v průběhu puerperia. Thesis, VŠV Brno 1967, 49 p.

GEORGIEV, S.: Proučvane na obšteta imunobiologična reaktivnost na organizma i mikrobnija sastav na matkata na kravi v puerperium. Vet. Med. Nauki, 15, 1978: 69-77.

HYPA, R. - KAHLCKE, A.: Auswertung von Antibiogrammen. Tierärżtl. Umschau, 33, 1978: 222-225.

KUBÍK, P. - GRYGAR, I.: Výskyt bakterií v lochiích krav z velkokapacitních provozù a stanovení jejich citlivosti k antibiotikủm. Ref. SVK, VŠV Brno 1978, 9 p. 
KUDLÁC, E. - VLČKK, Z.: Klinické změny na pohlavním ústrojí a obsah bakterií $\mathrm{v}$ dèloze krav po normálním porodu. Vet. Med. Praha, 15, 1970: 11-19.

KUDLÁČ, E. - MINÁR̆, M. - VLČEK, Z.: Die Beziehung der ausgeschiedenen Geschlechtshormone zur Dynamik der bakteriellen Kontamination der Gebärmutter bei Kühen post partum. Fortpflanzung Haust., 6, 1970: 331-339.

LASSO, A. - NEOGRÁDY, Z.: Gyakorlati közülmények között végzett antibiotikum rezistencia viszgálat és célzott terápiával kapcsolatos néhány tapasztalat. Mag. Állator. Lap., 35, 1980: $262-263$.

LLOYD, E. - McMAHON, K. J. - GIER, H. T. - MARION, G. B.: Uterus of the Cow after Parturition. Bacterial Content. A.m. J. Vet. Res., 29, 1968: 77-81.

LUGINBÜHL, A. - KÜPFER, U.: Bakteriologische Befunde im Geschlechtsapparat von Kühen im Puerperium. II. Beziehungen in Uterusinvolution, Ovaraktivität, Beschaffenheit des Cervicalschleims und Fruchtbarkeit. Schw. A. Tierheilkd., 122, 1980: 695-705.

MILOVSKÝ, M.: Antibiotiká v krmivách z hladiska zdravia zvierat a ludí. Imunoprofylaxia, $1979,3,47-58$.

POHL, P. - THOMAS, J.: Utilisation des antibiotiques $\mathrm{en}$ prcduction animale et risques d'apparition de souches résistantes chez l'homme. Ann. Méd. vét., 1977: 249-255.

SƯVEGES, T. - MOLNÁR, T.: Kórokozó baktériumok antibiotikum-erzékenysége 5 év (1970-1974) adatai alapján. Mag. Állatorv., Lap., 31, 1976: 155-160.

TROLLDENIER, H.: Die Resistenzentwicklung pathogener Keime aus veterinärmedizinischem Untersuchungsmaterial in den Jahren 1971 bis 1977. Mh. Vet. Med., 35, 1980: 460-467.

VLCEEK, Z.: Příspěvek $\mathrm{k}$ mikrobiální analýze puerperálních onemocnění pohlavního ústrojí u skotu. Vet. Med. Praha, 7, 1962: 577-586.

VIČEK, Z.: Dynamika bakteriální kontaminace dělohy krav $\mathrm{v}$ průběhu puerperia. Vet. Med Praha, 14, 1969: 449-454.

VLCEEK, Z. - VALENTA, J.: Stabilita chlortetracyklínu fo intrauterinní aplikaci. Veterinaria Spofa, 18, 1976: 47-55.

VLČEK, Z. - NĚMEČEK, R.: Dynamika bakteriální kontaminace dělohy skotu po intrauterinní aplikaci chlortetracyklinu. Veterinaria Srofa, 18, 1976: 57-64. 